\title{
On Generic Skill Development: An engineering perspective
}

\author{
Khoa N. Le* and Vivian W. Y. Tam \\ Email: K.Le@griffith.edu.au, V.Tam@griffith.edu.au \\ Griffith School of Engineering, Griffith University, Queensland, Australia \\ Both authors contribute equally to this paper \\ * Corresponding author, Griffith School of Engineering, Griffith University, PMB 50 \\ Gold Coast Mail Centre, QLD 9726, Australia. Tel: (+617)-5552-9175;
}

Fax: (+617)-5552-8065.

\begin{abstract}
This paper addresses ten generic skills set out by Engineers Australia from the engineering graduate perspective. Generic skills of electronic-engineering and civilengineering graduates are studied prior to graduation and after graduation. Detailed comparisons are made. Possible recommendations are also discussed.

Keywords: engineering, electronic, civil, education, generic skills, Australia
\end{abstract}

\section{INTRODUCTION}

Students have different levels of motivation and attitude about teaching and learning. They also have different responses to specific classroom environments and instructional practices [1]. Thus it can be said that the more thoroughly instructors understand the differences, the better chance they have of meeting the diverse learning needs of their students [2]. Three categories of diversity that have been shown to have important implications for teaching and learning are differences in students' learning styles, approaches to learning and intellectual development levels $[3]$.

Engineering combines the art and science of production. It is a pragmatic activity that draws on imagination, judgement, integrity and intellectual discipline to apply science, 
mathematics and practical experience to design and to operate useful objects and processes that meet the needs and expectations of people [4]. In particular, engineering is crucial in society because solutions to real world problems cannot always wait until phenomena which influence them are completely understood using rigorous scientific methodologies [5]. Thus engineers are required to find solutions even when aspects of the underlying science have not been resolved. Therefore, it should be noted that engineering education is an important issue for developments of future engineering industry [1, 6-9].

As such, engineering courses offer students multiple resources for learning. However, it is not clear how much time students devote to these resources or how effective they are to master the course material [10]. Employers attempt to shape employees' work identities through the organization of work [11]. However, they are partly constrained by employee expectations related to education and training, the occupational structure and the labour market [12]. Employees, individually and collectively, also attempt to influence how their work is performed and hence play an active role in shaping their own work identities [13]. Work identities are therefore influenced both by structural factors and the agency of employers and employees.

The aim of this paper is to provide insights on engineering students' perceptions of selected generic skills and attitude. From that, effective methods can be devised to more effectively improve their learning process and the development of future engineering industry. 


\section{ENGINEERS IN AUSTRALIA}

In Australia, there are about 44,822 professional engineers having a bachelor degree or above, and selecting an occupation title associated with management and nonmanagement specific professional engineering [14]. The largest occupational group in the area of engineering management is the production manager group with about 11,520 members. The largest occupational group in the area of technical professional engineering is the mechanical engineer group with about 4,572 members. Table 1 shows the number of members in each occupational group. For engineering management occupations, the percentage of degree-qualified people to non-degree qualified people approximately ranges from $18 \%$ to $56 \%$. For technical engineering occupations, the percentage of degree-qualified to non-degree-qualified people approximately ranges from $34 \%$ to $90 \%$. This means that in a number of occupations, less than $50 \%$ of members claiming to be professional engineers have an engineer degree.

$<$ Table 1>

The number of professional engineers in each State is shown in Table 2. New South Wales has the most engineers of at least 14,844 . North Territory has the least with about 318. The number of professional engineers in each state and territory by occupation is shown in Table 3.

$<$ Table 2>

$<$ Table 3>

Table 4 shows the percentage of academic disciplines for professional engineering and information technology occupations. Table 5 shows the degree discipline of all 
professional engineers in technical areas. The dominant academic disciplines for engineers are civil engineering with about $38 \%$, electrical and electronic engineering and technology with about $25 \%$, and process and resources engineering with about $16 \%$.

$<$ Table 4>

$<$ Table 5>

\section{ENGINEERS AUSTRALIA}

Engineers Australia is the national forum for engineering advancement and professional development of its members. The role of Engineers Australia includes activities that: i) advance the science and practice of engineering; ii) cultivate lifelong learning members; iii) promote contributions of the profession as widely as possible; iv) champion professional and ethical conducts; v) welcome those who wish to practice engineering; vi) allow members' aspirations to flourish; and stimulate and learn from their creativity and innovation; vii) celebrate excellence in engineering outcomes; viii) draw inspiration from engineering heritage; ix) sustain the integrity of the profession; and $\mathrm{x}$ ) take the lead in advocacy of the profession [15].

Members of Engineers Australia belong to a local division including divisions in Canberra, Newcastle, Northern Territory, Queensland, South Australia, Sydney, Tasmania, Victoria and Western Australia. Engineers Australia is represented throughout the world. It has groups based in Malaysia, Singapore and the United Kingdom. 
There are ten generic skills required for each engineer in the engineering industry set out by Engineers Australia, which include [15]: i) ability to apply knowledge of basic science and engineering fundamentals; ii) ability to effectively communicate engineers and the community; iii) in-depth technical competence in at least one engineering discipline; iv) ability to undertake problems, formulation and solutions; v) ability to utilize a system approach to design and to improve operational performance; vi) ability to effectively funcation as an individual and in multidisciplinary and multi-cultural teams, with the capacity to be a leader, a manager or an effective team member; vii) understanding of the social, cultural, global and environmental responsibilities of the professional engineer, and the need for sustainable development; viii) understanding of the principles of sustainable design and development; ix) understanding of professional and ethical responsibility and commiting to them; and $\mathrm{x}$ ) expectation of the need to undertake lifelong learning and capacity.

\section{RESEARCH METHODOLOGY}

The Bachelor of Engineering program at Griffith University consists of the following majors: electronic, civil, geotechnical and coastal. Electronic engineering is currently in high demand on the Gold Coast, Queensland with enrolment numbers more than doubled in the last two years. As such, it is necessary and important to conduct the survey in this discipline to more thoroughly understand the students and to also improve teaching and learning processes from the university perspective. The electronic-engineering program at Griffith University, Griffith School of Engineering on the Gold Coast produced 3 graduates in 2003 to 11 in 2006 with the job-finding rate of $100 \%$. Most Griffith electronic-engineering graduates are currently working in 
Queensland, Victoria and Western Australia. Griffith graduates on the Gold Coast are considered by employers as equally capable as graduates from other institutions such as the University of Queensland and Queensland University of Technology.

The first year of the program for all disciplines is the common year in which students learn basic skills and knowledge on report writing, mathematics, physics and laboratory. From the second year to the final year of the program, students are divided into different main streams corresponding to each discipline. In the last three years of the program, students learn specialised courses and projects in the specific discipline. For electronic-engineering students, programming plays an important role to student success because most assignment and laboratory work require strong programming knowledge. For civil-engineering students, project-oriented skills such as on-site practical experience are required. As such, there are differences in learning perception between these two main disciplines. Surveys collected from the civil-engineering and electronic-engineering students are conducted to show the differences in their generic skills, learning perspective and career goals upon graduation.

The survey was sent to 11 electronic-engineering graduates and 50 civil-engineering graduates. 61 responses have been received with the response rate of $100 \%$. The students were asked to rank the ten generic skills and their effectiveness in helping the students to fulfil their study needs and learning process. Each skill is given a weighting factor by the students ranging from 1 to 10 in which ' 1 ' is the least important and ' 10 ' the most important. 
To determine the relative ranking of the skills, the scores were transformed to indices using Equation (1) [16]:

$$
R I I=\frac{\sum w}{A N},
$$

where $w$ is the weighting given to each factor by the respondent, ranging from 1 to 10 in which ' 1 ' is the least important and ' 10 ' the most important; $A$ is the highest weight, in this study $A=10 ; N$ the total number of samples; and $R I I$ the relative important index, $0 \leq R I I \leq 1$.

After collecting the questionnaire responses, individual structured interviews were arranged with eight respondents, selected from different engineering disciplines: four from the electronic-engineering discipline, and four from the civil-engineering discipline. The interviews were intended to gather further comments; elaboration and interpretation on the results obtained from the questionnaire.

\section{RESULTS AND DISCUSSIONS}

The RII values before and after graduation of the generic skills in the survey are estimated so that thorough comparisons between the electronic and civil engineering majors can be made. It should also be noted that the RII values are not used to rank the generic skills but only to compare the skills possessed by graduates in the two majors. It should be noted that it is difficult to rank these ten generic skills which are equally listed based on their characteristics. From Table 6, the ten generic skills can be divided into three groups: technical generic skills of 1, 3, 4 and 5, communications generic skills of 2 and 6, and ethical generic skills of 7 to 10 . From this, it can be suggested that the ethical and technical generic skills can be considered as the most important, and the communications generic skills the least important. Ethical and 
technical skills reflect long-term goals, worthiness and achievement of engineers in terms of contributions to the society and their profession which has been recognised by Engineers Australia.

Table 6, Figure 1 and Figure 2 show the RII factors of the ten generic skills provided by the electronic-engineering and civil-engineering graduates before and after their graduation.

$<$ Table 6>

$<$ Figure 1>

$<$ Figure 2>

The first generic skill shown in Table 6, Figure 1 and Figure 2 show the confidence of the graduates in applying knowledge of basic science and engineering fundamentals to real-life problems. Both the electronic-engineering and civil-engineering disciplines show almost identical RII values which indicates that the program structure has been suitably designed for the students.

The second generic skill possesses identical RII values for the electronic-engineering students and a slight improvement for the civil-engineering students. This can be explained as because most civil-engineering students at Griffith University have to compulsory complete a 3-month practical experience in the industry in Australia or overseas, their communications skills in practical situations are better than electronicengineering students. The University Mobility in Asia and the Pacific program (UMAP) sponsored by the Department of Education, Science and Training (DEST) from the Australian Government also provides civil-engineering students 
opportunities to complete their professional work experience program overseas which has been eagerly anticipated. For civil-engineering students not choosing to complete their work experience overseas, they are required to complete a compulsory Industrial Affiliate Program (IAP) in which the students conduct research on projects offered by the industry. From the interview discussions with the students and the results obtained in Table 6, Figure 1 and Figure 2, the UMAP program appears to be more effective than the IAP program in improving student communications skills even though the former may lack in-depth technicality.

The third generic skill reflects the competence and confidence levels of electronicengineering students over civil-engineering students in applying in-depth technical knowledge to real-life problems. From Table 6, Figure 1 and Figure 2, electronicengineering students possess a higher confidence level than civil-engineering students which is mainly due to the rigorousness and technical contents of the electronic discipline over the civil-engineering discipline. Electronic-engineering students are usually stronger in mathematics and physics than civil-engineering students because the former students have to learn complicated mathematical concepts in the electronic-engineering discipline such as signal processing, digital signal processing, Fourier transform, power spectrum, calculus, image processing, system analysis and solid-state devices, whereas civil-engineering students have to learn less complicated concepts with less mathematical-based such as statistics, moment calculations and structures. Specifically, calculus is not strongly emphasized in the civil-engineering discipline which explains the higher confident level of electronic-engineering graduates upon graduation. The same argument can also be used to explain the fourth and fifth generic skills. 
The sixth generic skills concerns the ability to work in a team of electronicengineering and civil-engineering students in which the former students possess a lower RII value than that of the latter students which is consistent with previous findings in this study. From the survey results, civil-engineering students possess more effective communications skills as shown in the second generic skill and therefore it is expected that they have a higher RII value than that of the electronicengineering students. However, the RII value of electronic-engineering students upon graduation is higher than before graduation which shows that these students are aware of the fact that they must be able to work in a team environment to further progress their career in the workforce. One typical example showing the amount of communications required for electronic and civil engineers. Imagine that a group of engineers is responsible to design a high-rise building. The electrical engineers in the group only need to know the amount of cables and the number of Internet-connection points for successful installations. The civil engineers on the other hand, have to design the whole building structure, working out the number of floors, building direction then communicate with the other engineers in other disciplines on the fine details so that those engineers can complete their tasks. In this case, the civil engineers play the key role in coordinating and driving the whole project.

The seventh and eighth skills are lacking in electronic-engineering graduates with lower RII values upon graduation than before graduation. The civil-engineering graduates possess satisfactory $R I I$ values which show their awareness in sustainable development. This can be easily understood as civil engineers completed environmental-related courses in their program such as project control (fourth year), 
engineering management (third year) and construction engineering (third year). Even though electronic-engineering graduates completed engineering management (third year) and introduction to co-operational education courses (first year), it seems insufficient to make them aware of environmental issues associated with the engineering discipline.

The ninth skill concerns about ethics in engineering which shows similar results and expectations for both the electronic-engineering and civil-engineering disciplines. Engineers Australia's Code of Ethics establishes the standards that all of its members must adopt work habits and relationships [15]. It outlines the three principles that members should hold and nine tenets that they must comply with. The general notes in the general guidance section are used as a guide on how to interpret and apply the Code. They cover issues such as: i) interaction with the community; ii) areas of competence and descriptions of qualifications; iii) interaction with clients and employers; iv) interaction with colleagues; v) acting as an expert witness; vi) making public comments or statements; and vii) unauthorised release of information. It can be suggested that because of the influence of Engineers Australia, electronic-engineering and civil-engineering graduates possess satisfactory RII ethics values after graduation. The capacity of undertaking life-long learning is also clearly reflected in the tenth skill in Table 6, Figure 1 and Figure 2 which show almost identical RII values for both electronic-engineering and civil-engineering disciplines.

\section{RECOMMENDATIONS}

From Table 6, Figure 1 and Figure 2, it is clear that the civil-engineering graduates process a higher confidence level than the electronic-engineering graduates. The key 
point is to try to obtain a higher RII value from engineering graduates after graduation. The followings are recommended to improve the electronic-engineering program at Griffith University:

- To incorporate more compulsory management courses into the program to improve electronic-engineering graduate communication skill; and

- To make electronic-engineering graduates more aware of sustainable development.

In view of the above recommendations for the electronic-engineering program, the followings are recommended for the civil-engineering program:

- To introduce more mathematical-based courses to improve in-depth technicality; and

- To introduce civil-engineering graduates to some basic electronic-engineering concepts to improve their confidence and to be able to work effectively with electronic-engineering graduates.

\section{CONCLUSION}

Generic-skill development has been shown in this paper for electronic-engineering and civil-engineering graduates at Griffith University, Queensland, Australia. It has been found that the civil-engineering graduates possess more effective communications skills, the ability to work in a team and sustainable development upon graduation. Electronic-engineering graduates express confidence in applying basic knowledge to real-life problems and in-depth technical competence upon graduation. Recommendations have been made to further improve the quality of the civil-engineering and electronic-engineering programs by introducing more 
mathematical-based courses into the former program, and more communications and management courses into the latter program.

\section{REFERENCES}

1. Felder, R.M. and R. Brent, Understanding student differences. Journal of Engineering Education, 2005. 94(1): p. 57-72.

2. Hapburn, B., Graduates into engineering: attitudes and intentions of finalyear undergraduate engineers. Education and Training, 1992. 34(4): p. 20-26.

3. Ribeiro, L.R.C. and M.G.N. Mizukami, Problem-based learning: a student evaluation of an implementation in postgraduate engineering education. European Journal of Engineering Education, 2005. 30(1): p. 137-149.

4. Engineers Australia, The engineering profession: a statistical overview. 2006: Engineers Australia, Australia.

5. Burtner, J., The use of discriminant analysis to investigate the influence of non-cognitive factors on engineering school persistence. Journal of Engineering Education, 2005. 94(3): p. 335-338.

6. Bjorklund, S.A., J.M. Parente, and D. Sathanathan, Effects of faculty interaction and feedback on gains in student skills. Journal of Engineering Education, 2004. 93(2): p. 153-160.

7. Casar, J.R., Encouraging students' attitude of innovation in research universities. European Journal of Engineering Education, 2000. 25(2): p. 115121.

8. Chang, B.V., K.R. Tremblay, and B.H. Dunbar, An experimental approach to teaching universal design. Education, 2000. 121(1): p. 153-158.

9. Felder, R.M., G.N. Felder, and E.J. Dietz, The effects of personality type on engineering student performance and attitude. Journal of Engineering Education, 2002. 91(1): p. 3-17.

10. Taraban, R., et al., Giving students time for the academic resources that work. Journal of Engineering Education, 2004. 93(3): p. 205-210.

11. Brown, A., Engineering identities. Career Development International, 2004. 9(3): p. 245-273.

12. Sagebiel, F. and J. Dahmen, Masculinities in organizational cultures in engineering education in Europe: results of the Euroopean Union project WomEng. European Journal of Engineering Education, 2006. 31(1): p. 5-14.

13. Godfroy-Genin, A. and C. Pinault, The benefits of comparing grapefruits and tangerines: a toolbox for European cross-cultural comparisons in engineering education - using this toolbox to study gendered images of engineering among students. European Journal of Engineering Education, 2006. 31(1): p. 23-33.

14. Engineers Australia, How many professional engineers are there in Australia and other big questions? 2001: Engineers Australia, Australia.

15. Engineers Australia. Requirements for engineers. 2007 [cited $20072 \mathrm{March}$ ]; Available from: http://www.engineersaustralia.org.au/.

16. Tam, C.M., et al., Quest for continuous quality improvement for public housing construction in Hong Kong. Journal of Construction Management and Economics, 2000. 18(4): p. 437-446. 
Table 1: Professional engineers in engineering occupations [14]

\begin{tabular}{|c|c|c|c|c|c|c|}
\hline \multirow[t]{2}{*}{ Occupation } & \multicolumn{2}{|c|}{$\begin{array}{l}\text { Members with a Bachelor } \\
\text { or above }\end{array}$} & \multicolumn{2}{|c|}{$\begin{array}{c}\text { Member without a Bachelor } \\
\text { or above }\end{array}$} & \multicolumn{2}{|c|}{ Total members } \\
\hline & Number & Percentage & Number & Percentage & Number & Percentage \\
\hline $\begin{array}{l}\text { Construction } \\
\text { project } \\
\text { management }\end{array}$ & 1,597 & 26 & 4,494 & 74 & 6,091 & 5 \\
\hline Manufacturer & 3,883 & 18 & 17,626 & 82 & 21,509 & 19 \\
\hline $\begin{array}{l}\text { Engineer } \\
\text { manager }\end{array}$ & 6,466 & 56 & 5,015 & 44 & 11,481 & 10 \\
\hline $\begin{array}{c}\text { Production } \\
\text { manager }\end{array}$ & 11,520 & 28 & 29,561 & 72 & 41,081 & 36 \\
\hline $\begin{array}{c}\text { Civil } \\
\text { engineer }\end{array}$ & 3,137 & 80 & 792 & 20 & 3,929 & 3 \\
\hline $\begin{array}{l}\text { Electrical } \\
\text { engineer }\end{array}$ & 4,452 & 63 & 2,645 & 37 & 7,097 & 6 \\
\hline $\begin{array}{c}\text { Electronics } \\
\text { engineer }\end{array}$ & 4,709 & 61 & 3,019 & 39 & 7,728 & 7 \\
\hline $\begin{array}{l}\text { Mechanical } \\
\text { engineer }\end{array}$ & 4,572 & 61 & 2,944 & 39 & 7,516 & 7 \\
\hline $\begin{array}{c}\text { Production } \\
\text { or plant } \\
\text { engineer }\end{array}$ & 1,329 & 56 & 1,050 & 44 & 2,379 & 2 \\
\hline $\begin{array}{l}\text { Mining } \\
\text { engineer }\end{array}$ & 1,594 & 81 & 368 & 19 & 1,962 & 2 \\
\hline $\begin{array}{l}\text { Petroleum } \\
\text { engineer }\end{array}$ & 179 & 78 & 50 & 22 & 229 & 0 \\
\hline $\begin{array}{c}\text { Materials } \\
\text { engineer }\end{array}$ & 382 & 77 & 114 & 23 & 496 & 0 \\
\hline $\begin{array}{c}\text { Aeronautical } \\
\text { engineer }\end{array}$ & 208 & 65 & 113 & 35 & 321 & 0 \\
\hline $\begin{array}{l}\text { Agricultural } \\
\text { engineer }\end{array}$ & 57 & 34 & 109 & 66 & 166 & 0 \\
\hline $\begin{array}{c}\text { Biomedical } \\
\text { engineer }\end{array}$ & 133 & 53 & 117 & 47 & 250 & 0 \\
\hline $\begin{array}{l}\text { Chemical } \\
\text { engineer }\end{array}$ & 322 & 90 & 36 & 10 & 358 & 0 \\
\hline $\begin{array}{l}\text { Industrial } \\
\text { engineer }\end{array}$ & 213 & 61 & 138 & 39 & 351 & 0 \\
\hline $\begin{array}{c}\text { Naval } \\
\text { architect }\end{array}$ & 70 & 67 & 35 & 33 & 105 & 0 \\
\hline Total & 44,822 & 40 & 68,226 & 60 & 113,048 & 100 \\
\hline
\end{tabular}


Table 2: Professional engineers in each State [15]

\begin{tabular}{|c|c|c|c|c|}
\hline \multirow{2}{*}{ State } & $\begin{array}{c}\text { Members with a Bachelor } \\
\text { degree or above, and work in } \\
\text { an engineering occupation }\end{array}$ & $\begin{array}{c}\text { Members with a Bachelor } \\
\text { degree or above in engineering } \\
\text { or related technologies }\end{array}$ & \multirow{2}{*}{ Notal members } \\
\cline { 3 - 5 } & 14,844 & 64,073 & 78,917 & 33 \\
\hline New South Wales (NSW) & 11,898 & 51,359 & 63,257 & 27 \\
\hline Victoria (VIC) & 7,742 & 33,417 & 41,159 & 17 \\
\hline Queensland (QLD) & 2,769 & 11,951 & 14,720 & 6 \\
\hline South Australia (SA) & 5,898 & 25,460 & 31,358 & 13 \\
\hline Western Australia (WA) & 603 & 2,605 & 3,208 & 1 \\
\hline Tasmania (Tas) & 318 & 1,372 & 1,690 & 1 \\
\hline North Territory (NT) & 719 & 3,102 & 3,821 & 2 \\
\hline Australia Capital Territory (ACT) & 44,790 & 193,336 & 238,126 & 100 \\
\hline Total & & & \\
\hline
\end{tabular}


Table 3: Professional engineers in each State by occupation [15]

\begin{tabular}{|c|c|c|c|c|c|c|c|c|c|c|}
\hline Occupation & NSW & VIC & QLD & SA & WA & \multirow{2}{*}{ Tas } & \multirow{2}{*}{ NT } & ACT & \multicolumn{3}{|c|}{ Total } \\
\cline { 3 - 11 } & & & & & & & & \\
$\begin{array}{c}\text { Construction project } \\
\text { manager }\end{array}$ & 510 & 298 & 245 & 50 & 79 & 0 & 12 & 33 & 1,227 & 3 \\
\hline Engineering manager & 2,085 & 1,587 & 870 & 348 & 776 & 68 & 49 & 100 & 5,883 & 13 \\
\hline Production manager & 6,399 & 4,843 & 3,553 & 1,025 & 2,139 & 277 & 140 & 251 & 18,627 & 42 \\
\hline Electrical engineer & 1,646 & 839 & 794 & 266 & 523 & 113 & 33 & 62 & 4,276 & 10 \\
\hline Electronics engineer & 1,338 & 1,360 & 426 & 368 & 330 & 41 & 18 & 134 & 4,015 & 9 \\
\hline Mechanical engineer & 1,026 & 1,350 & 693 & 303 & 659 & 41 & 29 & 50 & 4,151 & 9 \\
\hline $\begin{array}{c}\text { Production or plant } \\
\text { engineer }\end{array}$ & 363 & 395 & 126 & 109 & 149 & 15 & 0 & 3 & 1,160 & 3 \\
\hline Mining engineer & 309 & 90 & 451 & 39 & 560 & 21 & 19 & 0 & 1,489 & 3 \\
\hline Petroleum engineer & 28 & 54 & 66 & 87 & 274 & 6 & 0 & 0 & 515 & 1 \\
\hline Materials engineer & 80 & 110 & 44 & 24 & 46 & 0 & 0 & 0 & 304 & 1 \\
\hline Aeronautical engineer & 160 & 192 & 73 & 30 & 9 & 0 & 3 & 43 & 510 & 1 \\
\hline Agricultural engineer & 15 & 12 & 20 & 0 & 0 & 0 & 0 & 0 & 47 & 0 \\
\hline Biomedical engineer & 93 & 88 & 14 & 18 & 24 & 0 & 0 & 3 & 240 & 1 \\
\hline Chemical engineer & 617 & 499 & 324 & 85 & 276 & 15 & 12 & 24 & 1,852 & 4 \\
\hline Industrial engineer & 167 & 175 & 39 & 15 & 51 & 6 & 3 & 15 & 471 & 1 \\
\hline Total & 14,836 & 11,892 & 7,738 & 2,767 & 5,895 & 603 & 318 & 718 & 44,767 & 100 \\
\hline
\end{tabular}


Table 4: Academic disciplines for professional engineers and information technology occupations [14]

\begin{tabular}{|c|c|c|c|c|c|c|c|c|c|c|}
\hline \multirow[t]{2}{*}{ Occupation } & 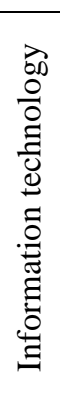 & 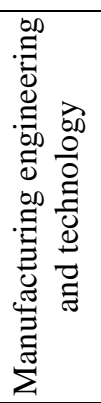 & 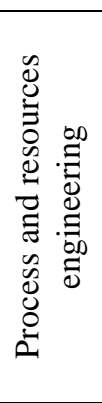 & 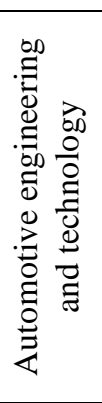 & 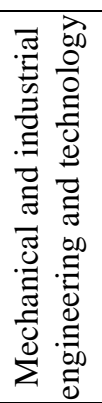 & 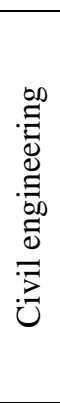 & 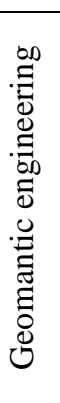 & 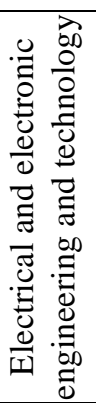 & 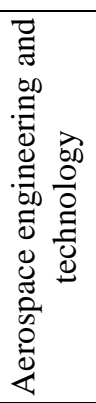 & 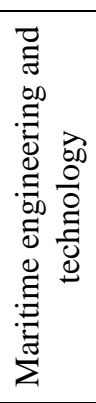 \\
\hline & \multicolumn{10}{|c|}{ (in $\%)$} \\
\hline $\begin{array}{c}\text { Construction project } \\
\text { manager }\end{array}$ & 1 & 0 & 4 & 0 & 6 & 83 & 3 & 4 & 0 & 0 \\
\hline Manufacturer & 5 & 3 & 35 & 0 & 26 & 13 & 0 & 18 & 0 & 1 \\
\hline Engineering manager & 2 & 1 & 10 & 0 & 24 & 32 & 1 & 29 & 1 & 0 \\
\hline $\begin{array}{c}\text { Production manager } \\
\text { (manufacturing) }\end{array}$ & 4 & 4 & 44 & 0 & 26 & 7 & 0 & 14 & 1 & 1 \\
\hline $\begin{array}{l}\text { Production manager } \\
\text { (mining) }\end{array}$ & 1 & 0 & 80 & 0 & 4 & 9 & 3 & 3 & 1 & 1 \\
\hline $\begin{array}{c}\text { Supply and } \\
\text { distribution manager }\end{array}$ & 14 & 3 & 23 & 0 & 18 & 19 & 1 & 15 & 3 & 4 \\
\hline $\begin{array}{c}\text { Information } \\
\text { technology manager }\end{array}$ & 72 & 0 & 2 & 0 & 3 & 3 & 2 & 18 & 1 & 0 \\
\hline Civil engineer & 0 & 0 & 1 & 0 & 2 & 96 & 0 & 1 & 0 & 0 \\
\hline Electrical engineer & 1 & 0 & 0 & 0 & 2 & 0 & 0 & 96 & 0 & 0 \\
\hline Electronics engineer & 11 & 1 & 0 & 0 & 2 & 1 & 0 & 85 & 0 & 0 \\
\hline Mechanical engineer & 0 & 1 & 7 & 0 & 83 & 3 & 0 & 3 & 1 & 0 \\
\hline $\begin{array}{c}\text { Production or plant } \\
\text { engineer }\end{array}$ & 1 & 4 & 40 & 0 & 39 & 3 & 0 & 11 & 2 & 0 \\
\hline Mining engineer & 0 & 0 & 91 & 0 & 3 & 3 & 1 & 1 & 0 & 0 \\
\hline Petroleum engineer & 1 & 2 & 66 & 0 & 21 & 8 & 0 & 3 & 0 & 0 \\
\hline Materials engineer & 0 & 0 & 80 & 0 & 8 & 7 & 0 & 5 & 0 & 0 \\
\hline Aeronautical engineer & 2 & 0 & 1 & 0 & 7 & 0 & 0 & 14 & 76 & 0 \\
\hline Agricultural engineer & 0 & 0 & 0 & 0 & 100 & 0 & 0 & 0 & 0 & 0 \\
\hline Biomedical engineer & 3 & 4 & 17 & 0 & 14 & 0 & 0 & 62 & 0 & 0 \\
\hline Chemical engineer & 1 & 0 & 78 & 0 & 5 & 14 & 0 & 2 & 0 & 0 \\
\hline Industrial engineer & 1 & 4 & 25 & 2 & 37 & 17 & 0 & 16 & 0 & 0 \\
\hline Naval architect & 0 & 0 & 0 & 0 & 6 & 0 & 0 & 3 & 0 & 91 \\
\hline Systems manager & 78 & 0 & 1 & 0 & 2 & 1 & 2 & 14 & 1 & 0 \\
\hline Systems designer & 65 & 0 & 2 & 0 & 2 & 2 & 1 & 27 & 0 & 0 \\
\hline Software designer & 61 & 0 & 1 & 0 & 2 & 1 & 1 & 31 & 1 & 0 \\
\hline $\begin{array}{l}\text { Applications and } \\
\text { analyst programmer }\end{array}$ & 83 & 0 & 1 & 0 & 2 & 1 & 1 & 11 & 0 & 0 \\
\hline Systems programmer & 83 & 0 & 1 & 0 & 2 & 1 & 1 & 11 & 0 & 0 \\
\hline $\begin{array}{c}\text { Computer systems } \\
\text { auditor }\end{array}$ & 82 & 0 & 2 & 0 & 0 & 0 & 0 & 16 & 0 & 0 \\
\hline
\end{tabular}


Table 5: Academic disciplines of professional engineers in technical areas [14]

\begin{tabular}{|c|c|}
\hline Degree discipline & Percentage of professional engineers \\
\hline Information technology & 3 \\
\hline Manufacturing engineering and technology & 1 \\
\hline Process and resources engineering & 16 \\
\hline Automotive engineering and technology & 0 \\
\hline $\begin{array}{c}\text { Mechanical and industrial engineering and } \\
\text { technology }\end{array}$ & 15 \\
\hline $\begin{array}{c}\text { Civil engineering } \\
\text { Geomatic engineering }\end{array}$ & 38 \\
\hline $\begin{array}{c}\text { Electrical and electronic engineering and } \\
\text { technology }\end{array}$ & 0 \\
\hline Aerospace engineering and technology & 25 \\
\hline Maritime engineering and technology & 1 \\
\hline Total & 100 \\
\hline
\end{tabular}


Table 6: Relative indices on different generic skills of electronic-engineering and civil-engineering disciplines before and after graduation

\begin{tabular}{|c|c|c|c|c|c|}
\hline & \multirow{3}{*}{ Generic skills } & \multicolumn{2}{|c|}{$\begin{array}{l}\text { Electronic- } \\
\text { engineering }\end{array}$} & \multicolumn{2}{|c|}{$\begin{array}{c}\text { Civil- } \\
\text { engineering }\end{array}$} \\
\hline & & \multicolumn{4}{|c|}{ RII } \\
\hline & & before & after & before & after \\
\hline 1 & $\begin{array}{c}\text { Ability to apply knowledge of basic science and engineering } \\
\text { fundamentals }\end{array}$ & 0.84 & 0.92 & 0.85 & 0.95 \\
\hline 2 & $\begin{array}{l}\text { Ability to effectively communicate with engineers and the } \\
\text { community }\end{array}$ & 0.86 & 0.86 & 0.84 & 0.86 \\
\hline 3 & In-depth technical competence in at least one engineering discipline & 0.74 & 0.80 & 0.72 & 0.75 \\
\hline 4 & Ability to undertake problems, formulation and solutions & 0.84 & 0.89 & 0.79 & 0.81 \\
\hline 5 & $\begin{array}{c}\text { Ability to utilize a system approach to design and to improve } \\
\text { operational performance }\end{array}$ & 0.82 & 0.85 & 0.82 & 0.82 \\
\hline 6 & $\begin{array}{l}\text { Ability to effectively function as an individual and in multi- } \\
\text { disciplinary and multi-cultural teams, with the capacity to be a } \\
\text { leader, a manager or an effective team member }\end{array}$ & 0.86 & 0.88 & 0.82 & 0.88 \\
\hline 7 & $\begin{array}{l}\text { Understanding of the social, cultural, global and environmental } \\
\text { responsibilities of the professional engineer, and the need for } \\
\text { sustainable development }\end{array}$ & 0.73 & 0.71 & 0.70 & 0.86 \\
\hline 8 & $\begin{array}{c}\text { Understanding of the principles of sustainable design and } \\
\text { development }\end{array}$ & 0.78 & 0.75 & 0.72 & 0.85 \\
\hline 9 & $\begin{array}{c}\text { Understanding of professional and ethical responsibility and } \\
\text { committing to them }\end{array}$ & 0.71 & 0.79 & 0.70 & 0.80 \\
\hline 10 & $\begin{array}{c}\text { Expectation of the need to undertake lifelong learning, and capacity } \\
\text { to do so }\end{array}$ & 0.72 & 0.86 & 0.75 & 0.83 \\
\hline
\end{tabular}




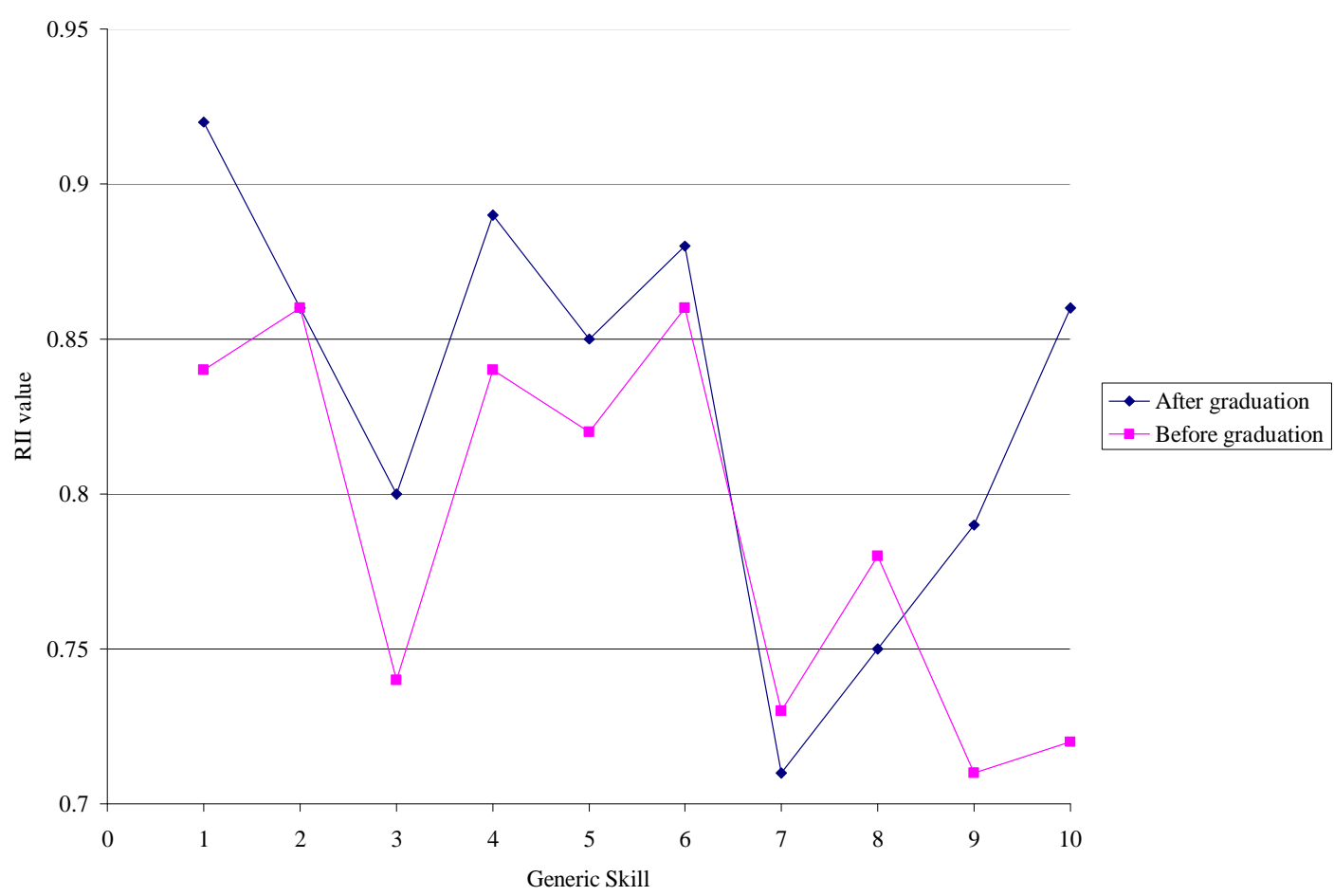

Figure 1: RII values of electronic-engineering students before and after graduation 


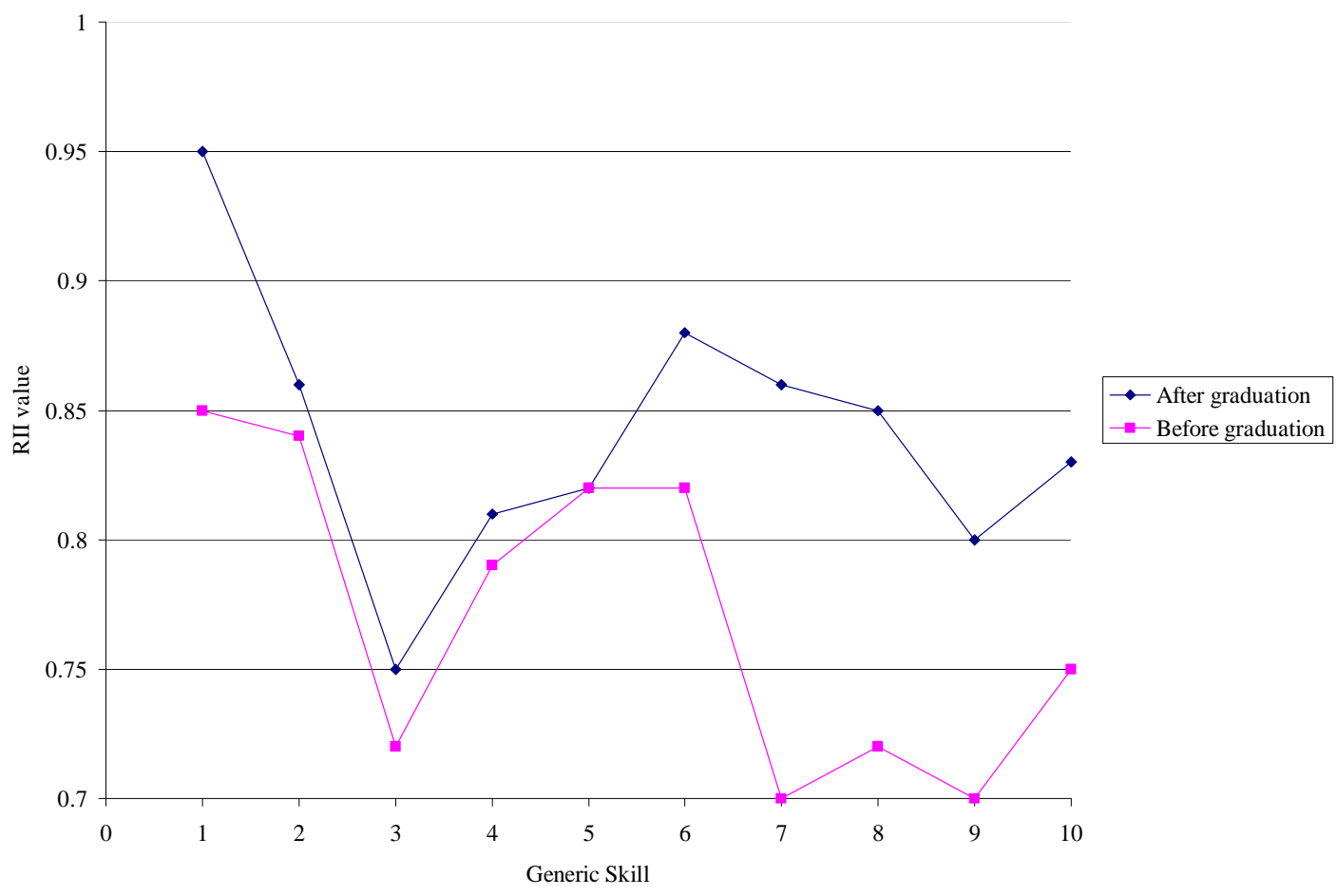

Figure 2: RII values of civil-engineering students before and after graduation 